\title{
Ratio Decidendi Terhadap Putusan Perampasan Aset Oleh Negara Dalam Perkara First Travel (Studi Putusan Nomor: 3096 K/Pid.Sus/2018)
}

\author{
Ratio Decidendi toward Confisted Good Verdict by the State on \\ First Travel Case \\ (A Case Study Number: 3096 K/Pid.Sus/2018)
}

\author{
Umar Boki \\ Bagian Akademi Pascasarjana Universitas Halu Oleo \\ E-mail: umarboki77@gmail.com \\ Oheo K. Haris \\ Pascasarjana Universitas Halu Oleo \\ E-mail: oheo.haris@uho.ac.id \\ Handrawan \\ Pascasarjana Universitas Halu Oleo \\ E-mail: handrawansaranani84@gmail.com
}

\begin{abstract}
This research is focused on analyzing of Verdict toward First Travel case with Number 3096/K/Pid.Sus/2018 that the judge did not argue the legal consistence. In the appeal court, the Judge has decided that the defendant was did not be accepted due to in this context (in casu). This study applies which is applied legislation and case, and theoretical approach. This research found that the Judges' interpretation by means of principle of benefit which is dealt with victim's recovery asset on money laundering that confiscated goods for the state was not actually be accepted. This argument was merely not applied either formal or material content. However, it is found the Judge's decision on confiscated judgment which is mentioned in the article 46 (1) Indonesian Procedural Penal Code (KUHAP) found was refused appealed defendant and strengthened the lower court with Number 83/Pid.B/2018/PN.Dpk. In this verdict was stated the defendant's conflicted goods was seizure by the state not by defendant. In fact, it is based on paragraph 46 article (1) KUHAP did not mention that the state does not have legal power to seizure the confiscated goods. Yet, all of confiscated goods should be return to the accused that has the rights.
\end{abstract}

Keywords: Ratio Decidendi; Judge's Decision; Asset Deprivation

Abstrak: Penelitian ini memfokuskan analisis putusan Hakim pada perkara First Travel Putusan Nomor: 3096/K/Pid.Sus/2018, memperlihatkan bahwa tidak dilaksanakannya terobosan hukum oleh Hakim. Pada tingkat kasasi, 
pertimbangannya hakim menyebutkan bahwa alasan kasasi para Terdakwa tidak dapat dibenarkan karena perkara in casu. Studi ini menggunakan penelitian hukum yang menerapkan undang-undang, teori, dan kasus. Penelitian ini menemukan bahwa penafsiran asas manfaat dalam Putusan MA dikaitkan dengan asset recovery korban tindak pidana pencucian uang yang disita untuk negara tidak tepat, karena telah melanggar hukum formal maupun materiil. Sedangkan Putusan perampasan aset First Travel dan Kesesuaiannya Dengan Pasal 46 (1) Kitab Undang-Undang Hukum Acara Pidana Bahwa telah terjadi kesalahan dalam putusan Hakim Mahkamah Agung yang menyatakan menolak permohonan kasasi dan menguatkan putusan sebelumnya yaitu tetap mengembalikan putusannya pada Pengadilan Tingkat Pertama yaitu Putusan PN Depok No. 83/Pid.B/2018/PN.Dpk dalam amar putusannya menetapkan barang-barang bukti dirampas untuk negara. Berdasarkan Pasal 46 Ayat (1) KUHAP, tidak ada sama sekali penjelasan mengenai adanya kewenangan negara untuk mengambil hasil barang sitaan, melainkan barang sitaan seharusnya dikembalikan kembali kepada orang yang berhak.

Kata kunci: Ratio Decidendi; Putusan Hakim; Perampasan Aset

\section{PENDAHULUAN}

Putusan Hakim merupakan tindakan akhir dari Hakim di dalam persidangan, menentukan apakah di hukum atau tidak seorang pelaku, jadi putusan Hakim adalah pernyataan dari seorang hakim dalam memutuskan suatu perkara di dalam persidangan dan memiliki kekuatan hukum tetap. Berlandaskan pada visi teoritis dan praktik peradilan maka putusan Hakim itu merupakan putusan yang di ucapkan oleh hakim karena jabatannya dalam persidangan perkara pidana yang terbuka untuk umum setelah melalui proses dan prosedural hukum acara pidana pada umumnya berisikan amar pemidanaan atau bebas atau pelepasan dari segala tuntutan hukum dibuat dalam bentuk tertulis dengan tujuan menyelesaikan perkara1.

Putusan hakim menjadi wewenang hakim dan didasarkan pada fakta-fakta suatu kasus yang dikenal sebagai res judicata, yang mengikat hanya tindakan para pihak yang berperkara. Suatu putusan dibuat antara res judicata dengan rasio decidendi, yang merupakan sesuatu yang lebih abstrak dan terserap masuk pada body of law ${ }^{2}$. Hanya putusan hakim dapat dibatalkan dan prosesnya dilaksanakan sesuai dengan peraturan perundang-undangan yang berlaku jika putusan tersebut belum adil bagi para pihak.

Berbicara putusan, maka terdapat putusan pengadilan tingkat pertama, tingkat banding, kasasi, dan peninjauan kembali (PK) serta putusan hak uji materi (judicial review)

1 Lilik Mulyadi, Kompilasi Hukum Pidana dalam Perspektif Teoritis dan Praktik Peradilan. Bandung: Mandar Maju, 2007, hlm. 127

2 Prahassacita Vidya, "Mengenal Ratio Recidendi", Business Law Binus University, https://businesslaw.binus.ac.id/2018/12/07/mengenal-ratio-decidendi/, diakses pada tanggal 11 November 2020. 
yang sering diterima oleh para pihak dalam persidangan. Putusan pengadilan pada tingkat pertama adalah putusan penyelesaian perkara, kemudian jika belum memberikan unsur keadilan, maka diajukan kasasi dan banding ke pengadilan. Tujuannya adalah untuk mendapatkan putusan inkracht atau putusan akhir. Putusan ini berkekuatan hukum tetap dan dapat diterima dengan baik oleh para pihak dalam persidangan.

Putusan yang berkekuatan hukum tetap (inkracht) adalah putusan yang telah diterima oleh kedua belah pihak tetapi tentu saja untuk mencapai putusan inkracht tersebut harus melewati putusan pertama dari pengadilan, putusan kasasi, banding, dan peninjauan kembali putusan yang telah dibuat. Dalam hal ini sebuah putusan hukum dari pengadilan memiliki proses yang sangat panjang dan waktu yang lama.

Putusan yang belum tepat bagi para pihak selalu diikuti dengan upaya hukum terhadap putusan hakim, hal ini sebagaimana Pasal 1 angka 12 KUHAP yang berbunyi:

“Upaya hukum adalah hak terdakwa atau penuntut umum untuk tidak menerima putusan pengadilan yang berupa perlawanan atau banding atau kasasi atau hak terpidana untuk mengajukan permohonan peninjauan kembali dalam hal serta menurut cara yang diatur dalam undang-undang ini3."

Pasal ini dapat menjadi bagian penting bagi para pihak untuk meminta keadilan ditegakkan dan tidak menimbulkan ketidakpuasan terhadap putusan hakim. Upaya menghindari adanya ketidakpuasan para pihak dalam persidangan, maka dewan hakim harus dapat memberikan putusan yang tepat dengan penafsiran dan pertimbangan hukum yang menjadi dasar sebelum memutuskan perkara.

Majelis Hakim dalam memberikan putusan selain berorientasi pada nilai kepastian hukum, diharapkan dapat berlandaskan pada prinsip/asas manfaat. Asas manfaat dalam putusan hakim diartikan bahwa dalam memutuskan suatu perkara hakim melakukan segala upaya dalam mengadili suatu perkara guna memberikan manfaat sebesar-besarnya untuk kepentingan pencari keadilan atau pihak yang berperkara. Masyarakat mengharapkan manfaat dalam pelaksanaan atau penegakan hukum. Hukum itu untuk manusia, maka pelaksanaan hukum atau penegakan hukum harus memberi manfaat atau kegunaan bagi masyarakat. Jangan sampai justru karena hukumnya dilaksanakan atau ditegakkan malah akan timbul keresahan di dalam masyarakat itu sendiri ${ }^{4}$

Salah satu perkembangan kasus tindak pidana penipuan dan pencucian uang oleh travel haji dan umrah ini dilakukan PT First Anugerah Karya Wisata atau yang biasa disebut

3 Kitab Undang-Undang Hukum Acara Pidana (KUHP).

4 Sudikno Mertokusumo. Penemuan Hukum Sebuah Pengantar, Yogyakarta: Liberty, 2009, hlm. 161. 
dengan First Travel. Putusan hukum terhadap perkara First Travel dengan Nomor Perkara 3096 K/Pid.Sus/2018 menimbulkan berbagai pertanyaan pada para calon jemaah umrah untuk dapat meminta pertanggung jawaban pihak perusahaan untuk mengembalikan yang telah disalahgunakan dalam bisnis bodong. Pengadilan telah menetapkan pemilik First Travel, Andika Surachman dan Annies Desvitasari Hasibuan dengan Nomor Perkara 3096 K/Pid.Sus/2018 serta Direktur Keuangan Siti Nuriada Hasibuan dinyatakan di tolak, sehingga putusan tersebut mengembalikan pada Putusan Pengadilan Negeri Depok, yang menyatakan memvonis masing-masing 20 tahun, 18 tahun dan 15 tahun penjara. Tetapi pengadilan tidak memberikan putusan untuk mengembalikan uang/dana milik nasabah.

Dalam perkara ini terlihat bahwa terdapat permasalahan mengenai bagaimana seharusnya perlakuan terhadap aset First Travel, apakah seharusnya dikembalikan kepada korban untuk mengembalikan kerugian korban, atau apakah putusan pengadilan sudah tepat dengan memutus aset First Travel dirampas untuk negara.

Dalam putusannya hakim dinilai tidak memenuhi Asas Keadilan, karena yang berhak menerima aset rampasan dari kejahatan First Travel seharusnya adalah para jamaah bukan negara. Sebab, uang hasil kejahatan bukanlah hasil korupsi dari Negara melainkan uang milik orang-perorangan yang telah menjadi korban penipuan dan pencucian uang oleh Travel Haji dan Umroh First Travel ini. Sehingga menarik untuk dikaji tentang Ratio Decidendi hakim dalam memberikan putusan pada kasus First Travel.

\section{METODE PENELITIAN}

Tipe penelitian yang digunakan yaitu penelitian hukum yang bersifat Normatif, yang merupakan suatu proses untuk menemukan aturan hukum, prinsip-prinsip hukum, maupun doktrin-doktrin hukum guna menjawab isu hukum yang dihadapi yang menghasilkan argumentasi, teori dan konsep baru sebagai preskripsi dalam menyelesaikan masalah yang dihadapi. 5 Dengan pendekatan penelitian yaitu Pendekatan Undang-Undang (Statute approach), Pendekatan Konseptual (Conceptual approach), Pendekatan Kasus (case approach). Sedangkan sumber bahan hukum yang digunakan adalah bahan hukum primer dan sekunder (studi kepustakaan), dengan analisis yang sifatnya preskripsi.

5 Peter Mahmud Marzuki, Penelitian Hukum, Jakarta: Kencana Group, 2005, hlm. 35. 
ANALISIS DAN PEMBAHASAN

Ratio Decidendi Dalam Putusan Menolak Permohonan Kasasi Perkara First Travel (Studi Putusan Nomor: 3096/K/Pid.Sus/2018)

First Travel mendapat perhatian Kementerian Agama setelah First Travel gagal memberangkatkan Jemaah umrah pada 28 Maret 2017 lalu, pada kejadian itu Jemaah diinapkan di Hotel sekitar Bandara Soekarno Hatta. Kementerian Agama pun melakukan klarifikasi, investigasi, advokasi, hingga mediasi dengan jemaah. Upaya klarifikasi pertama kali dilakukan pada 18 April 2017. Jemaah merasa dirugikan karena di antara mereka ada yang sampai gagal 3 kali berangkat umrah. Saat dimintai kejelasan, manajemen First Travel selalu berkelit. Saat pertemuan itu juga, Kemenag langsung menanyakan kejelasan kasus ini ke petinggi First Travel. Namun pihak manajemen tidak memberikan jawaban sama sekali.

Pada tanggal 22 Mei 2017 Kementerian Agama mengundang pihak First Travel untuk mediasi dengan jemaah. Mereka mengirimkan tim legal namun tidak dilanjutkan. Masalahnya adalah karena tim legal First Travel tidak dibekali surat kuasa. Di sisi lain di tanggal yang sama, 600 jemaah First Travel dari Jawa Timur mengadu ke DPR. 600 jemaah dari Jawa Timur itu telantar di Ibu Kota selama empat hari dan tak pernah tahu kapan akan diberangkatkan ke Tanah Suci. Kementerian Agama kembali memanggil First Travel pada 24 Mei 2017. Upaya ini pun gagal karena pihak manajemen tidak hadir.

Pada 2 Juni 2017, digelar mediasi antara pihak First Travel dengan sejumlah jemaah dari Bengkulu. Untuk ke sekian kalinya manajemen First Travel tidak ada solusi yang bisa diberikan. 10 Juli 2017 merupakan terakhir kalinya upaya mediasi dilakukan. Lagi-lagi mediasi gagal karena manajemen First Travel tidak hadir. Sebelas hari setelahnya yaitu pada tanggal 21 Juli 2017 Satuan Tugas Waspada Investasi Otoritas Jasa Keuangan (OJK) memerintahkan PT First Anugerah Karya Wisata untuk menghentikan penjualan paket promonya karena ada indikasi investasi ilegal dan penghimpunan dana masyarakat tanpa izin. First Travel juga tidak pernah menyampaikan data jamah yang mendaftar dan belum diberangkatkan. Dokumen ini sudah diminta sejak empat bulan lamanya.

Kementerian Agama mencabut izin operasional First Travel. Pencabutan izin dilakukan Kemenag karena First Travel telah melakukan pelanggaran undang-undang tentang penyelenggaraan ibadah haji. Hal ini akhirnya menyebabkan jemaah yang mengalami kerugian baik materi maupun imaterial, Pencabutan izin dilakukan karena PT First Anugerah Karya Wisata dinilai terbukti telah melakukan pelanggaran Pasal 65 huruf a 
Peraturan Pemerintah Nomor 79 Tahun 2012 tentang Pelaksanaan Undang-undang Nomor 13 Tahun 2008 tentang Penyelenggaraan Ibadah Haji.

Pada tanggal 30 Mei 2018, Pengadilan Negeri Depok menjatuhkan hukuman: Andika dihukum 20 tahun penjara, Anniesa dihukum 18 tahun penjara, Kiki dihukum 15 tahun penjara, Andika-Anniesa juga dihukum membayar denda masing-masing Rp 10 miliar subsider 3 bulan kurungan, dan Aset First Travel dirampas negara. Yang kemudian para terdakwa mengajukan upaya hukum banding melalui putusan Pengadilan Tinggi Jawa Barat No. 195/PID/2018/PT BDG tanggal 15 Agustus 2018 dan sampai pada tingkat kasasi.

Pada tingkat kasasi melalui Putusan Mahkamah Agung nomor: 3096/K/Pid.Sus/2018 menolak permohonan kasasi yang berarti memperkuat putusan PN Depok No. 83/Pid.B/2018/PN.Dpk. Majelis hakim berpendapat bahwa alasan kasasi selebihnya hanya merupakan penilaian hasil pembuktian yang bersifat penghargaan tentang suatu kenyataan. Alasan semacam itu tidak dapat dipertimbangkan dalam pemeriksaan pada tingkat kasasi, karena pemeriksaan dalam tingkat kasasi hanya berkenaan dengan tidak diterapkannya suatu peraturan hukum, atau peraturan hukum diterapkan tidak sebagaimana mestinya, atau apakah cara mengadili tidak dilaksanakan menurut ketentuan undang-undang, dan apakah Pengadilan telah melampaui batas wewenangnya, sebagaimana dimaksud dalam Pasal 253 Ayat (1) Undang-Undang Nomor 8 Tahun 1981.

Dalam pertimbangannya dikatakan; "Bahwa sebagaimana fakta di persidangan, barang-barang bukti tersebut merupakan hasil kejahatan yang dilakukan oleh para terdakwa dan disita dari para terdakwa yang telah terbukti selain melakukan tindak pidana penipuan juga terbukti melakukan tindak pidana pencucian uang. Oleh karenanya, berdasarkan ketentuan Pasal 39 KUHP jo. Pasal 46 KUHAP barang-barang bukti itu dirampas untuk negara." Namun, Majelis Hakim tidak menjelaskan lebih komprehensif mengenai Pasal 39 dan Pasal 46 Kitab Undang-Undang Hukum Acara Pidana (KUHAP).

Putusan Mahkamah Agung menyatakan bahwa seluruh aset First Travel yang menjadi barang bukti selama proses peradilan pidana dirampas untuk negara adalah tidak tepat. Penilaian ini penulis dasarkan pada argumentasi bahwa terdapat hak korban dalam aset-aset itu. menurut penulis telah terjadi jumping conclusion (didasarkan pada pertimbangan hukum yang prematur) dalam memutus status barang bukti yang disita tersebut. Karena adanya persinggungan antara perkara pailit dan pidana First Travel, 
Mahkamah Agung sebenarnya dapat dengan mudah mendefinisikan 'yang paling berhak' dalam perkara First Travel tersebut.

Peraturan Pemerintah No. 7 Tahun 2018 tentang Pemberian Kompensasi, Restitusi, dan Bantuan Kepada Saksi Korban, di mana disebutkan bahwa korban tindak pidana berhak memperoleh restitusi berupa:

a. ganti kerugian atas kehilangan kekayaan atau penghasilan;

b. ganti kerugian yang ditimbulkan akibat penderitaan yang berkaitan langsung sebagai akibat tindak pidana; dan/atau

c. penggantian biaya perawatan medis dan/atau psikologis.

Berdasarkan aturan-aturan tersebut, dapat disimpulkan bahwa pelaku tindak pidana wajib memulihkan kerugian korban yang disebabkan terjadinya tindak pidana tersebut. Hal ini seharusnya dapat berlaku dalam perkara First Travel sehingga pihak First Travel yang menjadi terpidana wajib memulihkan kerugian para calon Jemaah dengan mengembalikan atau mengganti rugi harta berupa uang milik para korban, walaupun sudah dijatuhi pidana penjara atas perbuatannya.

Adapun terkait kepastian hukum negara berhutang kepada rakyat terkait kekuatan hukum dari Surat Keputusan Kementerian Agama Nomor 589 Tahun 2017 yang menyatakan bahwa seluruh uang jemaah wajib kembali atau diberangkatkan. Selain itu kepastian hukum juga tidak terjamin dalam hal mekanisme pembagian barang sitaan. Sehingga apabila kita melihat dari sisi lain, Majelis Hakim lebih memilih untuk memutuskan barang bukti yang disita dari First Travel dirampas untuk Negara. Karena Majelis hakim menilai sulit untuk menentukan siapa yang berhak untuk menerima pengembalian barang bukti tersebut dan mengkhawatirkan korban akan memperebutkan aset yang disita jika dikembalikan kepada pihak korban. Untuk mencegah ketidakpastian hukum atas aset tersebut majelis hakim menganggap adil jika aset yang disita dirampas untuk Negara.

Kepastian hukum yang dijadikan alasan Majelis Hakim untuk merampas aset First Travel bukanlah suatu kepastian hukum yang diharapkan karena peneliti menilai kepastian hukum yang dimaksud oleh Majelis Hakim tidaklah memberikan suatu kemanfaatan dan keadilan bagi para korban. Sehingga, akan lebih tepat jika hakim memutuskan untuk dikembalikan kepada korban. 


\section{Putusan Perampasan Aset First Travel oleh Negara Telah Sesuai Dengan Pasal 46 Ayat}

\section{(1) Kitab Undang-Undang Hukum Acara Pidana (KUHAP)}

Indonesia menganut sistem pembuktian menurut undang-undang secara negatif (negatief wettelijk bewijstheorie). Menurut M. Yahya Harahap sistem pembuktian ini menggabungkan antara sistem pembuktian menurut keyakinan hakim dengan sistem pembuktian menurut undang-undang secara positif. ${ }^{6} \mathrm{Hal}$ ini dapat dilihat dalam pengaturan Pasal 183 KUHAP bahwa seorang hakim tidak boleh menjatuhkan pidana apabila belum memperoleh sekurang-kurangnya dua alat bukti yang sah sebagaimana yang telah disebutkan dan diatur di dalam Pasal 184 KUHAP. Oleh karena itu kita mengenal asas Unus Testis Nullus Testis yang kerap ditemui di negara-negara yang menganut sistem pembuktian menurut undangundang secara negatif.

Berdasarkan sistem pembuktian yang telah diuraikan di atas, dalam hal pemidanaan seorang terdakwa, hakim haruslah mendasarkan pemidanaannya tersebut pada pembuktian yang berganda (dubbelen grondslag) yakni pada Undang-Undang dan Keyakinan Hakim. Pertama, pembuktian harus dilakukan menurut undang-undang (undang-undang telah menentukan dan menyebutkan alat-alat bukti yang sah dalam peradilan pidana). Kedua, keyakinan hakim harus didasarkan dengan alat bukti yang sah. ${ }^{7}$

Undang-Undang Kekuasaan Kehakiman memberikan kewenangan untuk menemukan hukum (rechtsvinding). Undang-Undang ini menjadi jaminan terhadap Kebebasan hakim yang didasarkan pada kemandirian kekuasaan kehakiman secara konstitusional diatur dalam Undang-Undang Dasar 1945, yang selanjutnya diimplementasikan ke dalam Undang-undang Nomor 14 Tahun 1970 tantang Pokok-pokok Kekuasaan Kehakiman dan Undang-Undang Nomor 35 Tahun 1999 tentang perubahan Undang-Undang Nomor 14 Tahun 1970, yang kemudian diganti dengan Undang-Undang Nomor 4 Tahun 2004 tentang Kekuasaan Kehakiman, dan selanjutnya diganti lagi dengan Undang-Undang Nomor 48 Tahun 2009 tentang Kekuasaan Kehakiman.

Pada hakikatnya semua perkara membutuhkan metode penemuan hukum agar aturan hukumnya dapat diterapkan secara tepat terhadap peristiwanya, sehingga dapat

6 Yahya M. Harahap, Pembahasan Permasalahan dan Penerapan KUHAP: Pemeriksaan Sidang Pengadilan, Banding, Kasasi, dan Peninjauan Kembali, Jakarta: Sinar Grafika, 2000, hlm. 278.

7 Aristo M.A. Pangaribuan, Arsa Mufti, Ichsan Zikry, Pengantar Hukum Acara Pidana di Indonesia, Jakarta: Raja Grafindo, 2017, hlm. 277. 
diwujudkan putusan hukum yang diidam-idamkan, yaitu yang mengandung aspek keadilan, kepastian hukum, dan kemanfaatan. ${ }^{8}$

Dalam konteks penegakan hukum tindak pencucian uang pada dasarnya Hakim menganut penemuan hukum heteronomi, sepanjang hakim terikat pada undang-undang. Tetapi dalam penemuan hukum itu juga mempunyai unsur otonom yang kuat, karena hakim seringkai harus menjelaskan atau melengkapi undang-undang menurut pandangannya sendiri. Sebagai contoh kalau ada hakim Pengadilan Negeri yang mengacu kepada putusan hakim di atasnya (PT atau MA), tetapi asasnya tetap bahwa hakim tidak terikat pada putusan hakim lain. Hal ini merupakan sifat otonom. Mengacunya hakim pada putusan hakim lain, tidak berarti menganut asas the binding force of precedent, seperti dianut oleh negara-negara Anglo Saxon, tetapi karena adanya keyakinan bahwa putusan yang dianutnya itu memang tepat (the persuacive force of precedent). ${ }^{9}$

MA dalam putusannya No. 3096 K/Pid.Sus/2018 berpandangan bahwa barang bukti tersebut dirampas untuk negara. Ada dua hal yang menjadi pertimbangan Mahkamah dalam menetapkan hal itu yaitu sebagai berikut:

1. Menurut Mahkamah, dalam fakta hukum di persidangan ternyata Pengurus Pengelola Aset Korban First Travel menyampaikan surat dan pernyataan penolakan menerima pengembalian barang bukti tersebut. Hal ini dinyatakan dalam Putusannya No. 3096 K/Pid.Sus/2018, yaitu:

"Bahwa sebagaimana fakta di persidangan barang-barang bukti tersebut merupakan hasil kejahatan yang dilakukan oleh para Terdakwa dan disita dari para Terdakwa yang telah terbukti selain melakukan tindak pidana "Penipuan" juga terbukti melakukan tindak pidana "Pencucian Uang" oleh karenanya berdasarkan ketentuan Pasal 39 KUHP jo. Pasal 46 KUHAP barang-barang bukti tersebut dirampas untuk Negara."

Pertimbangan Mahkamah itu memperkuat pertimbangan Majelis Hakim Tingkat Pertama (PN Depok) No. 83/Pid.B/2018/PN.Dpk, yang juga menyatakan bahwa fakta hukum di persidangan bahwa Pengurus Pengelola Aset Korban First Travel menyampaikan surat dan pernyataan penolakan menerima pengembalian barang bukti tersebut.

\footnotetext{
8 Bambang Sutiyoso, Metode Penemuan Hukum: Upaya Mewujudkan Hukum yang Pasti dan Berkeadilan, Yogyakarta: UII Press, 2006, hlm. 28.

9 Ibid., hlm. 40.
} 
2. Menurut Mahkamah bahwa fakta di persidangan barang-barang bukti tersebut merupakan hasil kejahatan yang dilakukan oleh para terdakwa dan disita dari para terdakwa yang telah terbukti selain melakukan tindak pidana "penipuan" juga terbukti melakukan tindak pidana "pencucian uang", oleh karenanya berdasarkan ketentuan Pasal 39 KUHP jo. Pasal 46 KUHAP barangbarang bukti tersebut dirampas untuk Negara.

3. Pasal 46 KUHAP menyebutkan;

(1) Barang-barang kepunyaan terpidana yang diperoleh dari kejahatan atau yang sengaja dipergunakan untuk melakukan kejahatan, dapat dirampas;

(2) Dalam hal pemidanaan karena kejahatan yang tidak dilakukan dengan sengaja atau karena pelanggaran, dapat juga dijatuhkan putusan perampasan berdasarkan hal-hal yang ditentukan dalam undang-undang;

(3) Perampasan dapat dilakukan terhadap orang yang bersalah yang diserahkan kepada pemerintah, tetapi hanya atas barangbarang yang telah disita.

Terkait dengan kedua pertimbangan Mahkamah di atas, menurut analisis penulis, dapat diajukan pertanyaan; pertama, atas dasar alat bukti apakah Mahkamah menyatakan bahwa Pengurus Pengelola Aset Korban First Travel menyampaikan surat dan pernyataan penolakan menerima pengembalian barang bukti? Kedua, apakah jika juga terbukti melakukan tindak pidana "pencucian uang" secara otomatis barang-barang bukti tersebut dirampas untuk negara? Sementara dapat dipahami bahwa pencucian uang adalah istilah yang digunakan untuk menggambarkan perolehan uang secara tidak sah dan menggunakannya seolah-olah tampak diperoleh secara sah. ${ }^{10}$

Dalam perkara tindak pidana pencucian uang haruslah ada suatu hubungan yang logis antara perampasan aset, pengembalian dan perihal yang berhak menerima kembali aset-aset tersebut. Menurut penulis bahwa ketika Majelis Hakim sampai tingkat Mahkamah Agung (kasasi) memutus seluruh barang bukti yang bernilai ekonomis dirampas untuk negara, sebenarnya telah terjadi suatu kekeliruan penerapan hukum material dimana pada kasus ini Hakim menggunakan logika penerapan hukum dengan menyamakannya pada tindak pidana korupsi yang merugikan keuangan negara (posisi negara sebagai korban dan warga negara sebagai pelaku dan korban), bukan memosisikan Negara sebagai pemberi perlindungan dan penjamin kepastian hukum bagi warga negaranya.

10 Sabrina Hidayat, Tinjauan Yuridis Kewenangan Komisi Pemberantasan Korupsi Melakukan Penyidikan Penggabungan Perkara Tindak Pidana Korupsi dan Pencucian Uang, Halu Oleo Law Review, Volume 1 Issue 2, September 2017. hlm. 180-195. 
Putusan Hakim pada perkara First Travel Putusan Nomor: 3096/K/Pid.Sus/2018, memperlihatkan bahwa tidak dilaksanakannya terobosan hukum oleh Hakim. Pada ditingkat kasasi, pertimbangannya hakim menyebutkan bahwa alasan kasasi para Terdakwa tidak dapat dibenarkan karena perkara in casu bukanlah perkara perdata semata akan tetapi sebagaimana fakta hukum yang terungkap di persidangan perkara a quo jelas merupakan perkara tindak pidana, maka seharusnya menurut penulis karena vonis yang dijatuhkan adalah hukuman pidana, hakim pengadilan pidana semestinya tidak melampaui kewenangannya dan dapat menyerahkan barang bukti aset kepada korporasinya untuk kemudian dapat berurusan secara perdata dengan para korban. Sehingga, Hakim kamar pidana Mahkamah Agung, semestinya tidak ikut mengambil keputusan yang bersifat perdata.

Pertimbangan Hakim Mahkamah Agung dalam tingkat kasasi cenderung mengedepankan pertimbangan hukum normatif dengan mengabaikan nilai-nilai hukum dan rasa keadilan yang hidup dalam masyarakat, sehingga tak jarang putusan tersebut menimbulkan kontroversi. Penalaran hukum hakim tingkat kasasi lebih mengedepankan pada kaidah normatif dan legalitas formal. Akibatnya putusan hakim Mahkamah Agung menunjukkan polarisasi pemikiran yang parsial dimana hakim melahirkan suatu putusan yang tampak benar padahal sebenarnya kurang tepat, serta etis yaitu polarisasi pemikiran yang sangat kontekstual tanpa adanya terobosan hukum dan pragmatis.

Penafsiran asas manfaat dalam Putusan MA dikaitkan dengan asset recovery korban tindak pidana pencucian uang yang disita untuk negara tidak tepat, karena telah melanggar hukum formal maupun materiil. Sehingga putusan yang dihasilkan akan menimbulkan permasalahan hukum di kemudian hari. Asas manfaat yang diterapkan oleh majelis hakim telah mengabaikan keadilan dan kepastian hukum. Negara dalam tindak pidana pencucian uang tersebut tidak pernah dirugikan, karena yang mengalami kerugian adalah individu/perorangan (Jemaah Haji).

Hakim dalam putusannya tidak seharusnya menyatakan aset First Travel dirampas untuk negara, karena tidak ada unsur kerugian negara, kasus ini juga bukanlah pidana korporasi yang memungkinkan asetnya dirampas untuk negara, dan ada sita umum sebagai sita paling tinggi berdasarkan peraturan perundang-undangan yang mengharuskan aset tersebut dikembalikan kepada kurator untuk dibagikan secara proporsional dan merata. Putusan hakim dari sisi korban tidak terpenuhinya rasa keadilan dalam putusan ini, tidak juga ada kemanfaatan hukum yang terkandung dalam putusan ini. Mengingat sampai pada 
tingkat Kasasi, Hakim tetap menyatakan aset dirampas untuk negara yang sejatinya tidak ada sedikit pun kerugian negara yang dialami.

Perampasan barang bukti oleh Negara tidak memberikan kebahagiaan yang sebesar-besarnya bagi pihak korban First Travel. Padahal semestinya penilaian terhadap baik-buruk atau adil-tidaknya suatu hukum bergantung kepada apakah hukum itu memberikan kebahagiaan kepada manusia atau tidak. Dengan demikian, berarti bahwa setiap penyusunan produk hukum (peraturan perundang-undangan) maupun suatu putusan pengadilan seharusnya senantiasa memperhatikan salah satu tujuan hukum yaitu untuk memberikan kebahagiaan sebanyak-banyaknya bagi masyarakat. Padahal seharusnya perampasan aset pelaku kejahatan dimaksudkan untuk memulihkan kerugian pada korban. Hal ini tentu dimaksudkan untuk meminimalkan kerugian ekonomi korban kejahatan tindak pidana pencucian uang, sebagaimana yang dilakukan oleh First Travel.

Seharusnya melalui Hakim Negara berkewajiban melindungi segenap bangsa Indonesia, sesuai Pembukaan UUD 1945. Jika demikian, maka merampas barang-barang bukti untuk negara tidaklah sesuai dengan semangat dan tujuan negara. Maka, mengembalikan barang-barang bukti kepada para Calon Jamaah Umroh lebih sejalan dengan semangat dan tujuan negara untuk melindungi segenap bangsanya.

Hal tersebut terbukti dari para jamaah yang sama sekali tidak merasakan keadilan dengan adanya putusan Mahkamah Agung tersebut. Padahal sejatinya berdasarkan konsep welfare state modern, negara tidak lagi sebagai negara polis yang hanya menjaga ketertiban melainkan hadirnya negara untuk memberikan kemanfaatan untuk kemakmuran rakyat. Ini telah menjadi amanah ideologi dan konstitusi.

\section{KESIMPULAN}

Putusan Hakim pada perkara First Travel Putusan Nomor: 3096/K/Pid.Sus/2018, memperlihatkan bahwa tidak dilaksanakannya terobosan hukum oleh Hakim. Pada tingkat kasasi, pertimbangannya hakim menyebutkan bahwa alasan kasasi para Terdakwa tidak dapat dibenarkan karena perkara in casu bukanlah perkara perdata semata akan tetapi sebagaimana fakta hukum yang terungkap di persidangan perkara a quo jelas merupakan perkara tindak pidana. Penafsiran asas manfaat dalam Putusan MA dikaitkan dengan asset recovery korban tindak pidana pencucian uang yang disita untuk negara tidak tepat, karena telah melanggar hukum formal maupun materiil. Asas manfaat yang diterapkan oleh majelis hakim telah mengabaikan keadilan dan kepastian hukum. Negara dalam tindak pidana 
pencucian uang tersebut tidak pernah dirugikan, karena yang mengalami kerugian adalah individu/perorangan (Jemaah Haji). Selain itu, Putusan Perampasan Aset First Travel oleh Negara dan Kesesuaiannya Dengan Pasal 46 (1) Kitab Undang-Undang Hukum Acara Pidana. Bahwa telah terjadi kesalahan dalam putusan Hakim Mahkamah Agung yang menyatakan menolak permohonan kasasi. Pertimbangan Hakim Mahkamah Agung dalam tingkat kasasi cenderung mengedepankan pertimbangan hukum normatif dengan mengabaikan nilai-nilai hukum dan rasa keadilan yang hidup dalam masyarakat, Akibatnya putusan Hakim Mahkamah Agung menunjukkan polarisasi pemikiran yang parsial dimana hakim melahirkan suatu putusan yang tampak benar padahal sebenarnya kurang tepat.

\section{Daftar Pustaka}

\section{Buku}

Harahap, Yahya M., Pembahasan Permasalahan dan Penerapan KUHAP: Pemeriksaan Sidang Pengadilan, Banding, Kasasi, dan Peninjauan Kembali, Jakarta: Sinar Grafika, 2000. Marzuki, Peter Mahmud, Penelitian Hukum, Jakarta: Kencana Group, 2005.

Mertokusumo, Sudikno. Penemuan Hukum Sebuah Pengantar, Yogyakarta: Liberty, 2009. Mulyadi, Lilik, Kompilasi Hukum Pidana dalam Perspektif Teoritis dan Praktik Peradilan. Bandung: Mandar Maju, 2007.

Pangaribuan, Aristo M.A., Arsa Mufti, Ichsan Zikry, Pengantar Hukum Acara Pidana di Indonesia, Jakarta: Raja Grafindo, 2017.

Sutiyoso, Bambang, Metode Penemuan Hukum: Upaya Mewujudkan Hukum yang Pasti dan Berkeadilan, Yogyakarta: UII Press, 2006.

\section{Jurnal dan Makalah}

Hidayat, Sabrina, Tinjauan Yuridis Kewenangan Komisi Pemberantasan Korupsi Melakukan Penyidikan Penggabungan Perkara Tindak Pidana Korupsi dan Pencucian Uang, Halu Oleo Law Review, Volume 1 Issue 2, September 2017. hlm. 180-195.

\section{Peraturan Perundang-undangan}

Undang-Undang Nomor 1 Tahun 1946 tentang Kitab Undang-undang Hukum Pidana. Undang-Undang Nomor 8 Tahun 1981 tentang Kitab Undang-Undang Hukum Acara Pidana. Peraturan Pemerintah Nomor 79 Tahun 2012 tentang Pelaksanaan Undang-undang Nomor 13 Tahun 2008 tentang Penyelenggaraan Ibadah Haji. 
Peraturan Pemerintah Nomor 7 Tahun 2018 tentang Pemberian Kompensasi, Restitusi, dan Bantuan Kepada Saksi Korban.

Putusan Mahkamah Agung Nomor: 3096/K/Pid.Sus/2018.

Putusan Pengadilan Tinggi Jawa Barat di Bandung Nomor: 195/Pid/2018/PT BDG.

Putusan Pengadilan Negeri Depok Nomor: 83/Pid.B/2018/PN.Dpk.

\section{Situs Web}

Vidya, Prahassacita, "Mengenal Ratio Recidendi", Business Law Binus University, https://business-law.binus.ac.id/2018/12/07/mengenal-ratio-decidendi/, diakses pada tanggal 11 November 2020. 